\begin{tabular}{cc|c}
\hline Tar. Bil. Der. & Journal of Agricultural Sciences \\
& $\begin{array}{c}\text { Dergi web sayfası: } \\
\text { www.agri.ankara.edu.tr/dergi }\end{array}$ & Journal homepage: \\
& www.agri.ankara.edu.tr/journal
\end{tabular}

\title{
Effect of Humic Substance Applications on Mineral Nutrition and Yield of Granny Smith and Jersey Mac Apple Varieties
}

\author{
Murat CANSU, ${ }^{\mathrm{a}}$, Ibrahim ERDAL ${ }^{\mathrm{b}}$ \\ ${ }^{a}$ Fruit Growing Research Station, Eğirdir, Isparta, TURKEY \\ ${ }^{\boldsymbol{b}}$ Suleyman Demirel University, Faculty of Agriculture, Department of Soil Science and Plant Nutrition, 32260, Isparta, TURKEY
}

\section{ARTICLE INFO}

Research Article DOI: 10.15832/ankutbd.446432

Corresponding Author: İbrahim ERDAL, E-mail: ibrahimerdal@sdu.edu.tr, Tel: +90 (246) 2118591

Received: 25 October 2016, Received in Revised Form: 06 December 2016, Accepted: 14 December 2016

\begin{abstract}
This study was conducted to examine the effect of soil, leaf and soil+leaf applications of humic substance on fruit yield, some quality parameters and mineral nutrition of Granny Smith and Jersey Mac apple varieties grafted on MM106 rootstock. The study was carried out for two consecutive years. According to the results obtained from both years, humic substance applications had no significant effect on fruit yield and quality parameters generally, but relative increases were recorded in yields. Leaf N, K, Ca, Fe and $\mathrm{Zn}$ concentrations were significantly affected from the applications. At the first year, humic substance application significantly affected only $\mathrm{N}$ and $\mathrm{K}$ concentrations of Jersey Mac variety, but in the second year, humic substance applications led to increase in leaf $\mathrm{N}, \mathrm{K}, \mathrm{Ca}, \mathrm{Fe}$ and $\mathrm{Zn}$ concentrations in Granny Smith and $\mathrm{N}$ concentration in Jersey Mac apple variety. According to the results obtained, it can be said that the effects of humic substances were higher than the first year's effects mostly.
\end{abstract}

Keywords: Fruit productivity; Fruit quality; Humic material; Nutrient concentration

\section{Humik Madde Uygulamalarının Granny Smith ve Jersey Mac Elma Çeşitlerinin Mineral Beslenmesine ve Verimine Etkisi}

\section{ESER BİLGİSi}

Araştırma Makalesi

Sorumlu Yazar: İbrahim ERDAL, E-posta: ibrahimerdal@sdu.edu.tr, Tel: +90 (246) 2118591

Geliş Tarihi: 25 Ekim 2016, Düzeltmelerin Gelişi: 06 Aralık 2016, Kabul: 14 Aralık 2016

\section{ÖZET}

Bu araştırma, MM106 anacına aşılanmış Granny Smith ve Jersey Mac elma çeşitlerinin verimi, kalitesi ve mineral beslenmesi üzerine humik maddenin toprak, yaprak ve toprak+yaprak uygulamalarının etkisini incelemek amaçlanmıştır. Deneme ardışı iki yıl yürütülmüştür. Araştırma sonunda, humik madde uygulamalarının meyvenin verim ve kalite ölçütleri üzerine genellikle anlamlı bir etkisi olmazken, meyve verimlerinde nisbi artışlar kaydedilmiştir.Yaprağın $\mathrm{N}, \mathrm{K}, \mathrm{Ca}, \mathrm{Fe}$ ve Zn konsantrasyonları hümik madde uygulamalarından olumlu etkilenmiştir. İlk yıl, humik madde uygulamaları sadece Jersey Mac çeşidinin N ve K konsantrasyonlarını etkilemiştir. Buna karşılık ikinci yıl humik madde 
uygulamaların Granny Smith çeşidinin N, K, Ca, Fe ve Zn konsantrasyonlarını, Jersey Mac çeşidinin ise N konsantrasyonunu artırdığı görülmüştür. Elde edilen sonuçlara göre, humik madde uygulamalarının ikinci yıldaki etkisinin, birinci yıla oranla daha fazla olduğu söylenebilir.

Anahtar Kelimeler: Meyve verimliliği; Meyve kalitesi; Humik madde; Besin elementi içeriği

(C) Ankara Üniversitesi Ziraat Fakültesi

\section{Introduction}

Turkey is one of the most important apple producing countries in the world. Apple production in Turkey was estimated as $3.1 \%$ of the world apple production. Although, Isparta is a very important apple growing region with the production nearly $26 \%$ of the country (TÜIKK 2014), the yield and quality is not satisfactory. There might be several factors for this, but one of the main reasons of this is unfavorable soil condition due to low organic matter, some nutrient deficiencies and unavailability of nutrients (Erdal et al 2004).

Soil fertility is defined as condition or state which the soil can supply sufficient amount of nutrient for healthy plant growth. Soil organic matter is an important soil component that increases and keeps sustainability of soil fertility by means of many physical, chemical and biological effects. Soil organic matter increases water and heat holding capacity, improves drainage, aeration and aggregation, increases microbial activity by means of decomposition products, improves soil $\mathrm{pH}$, lime content, cation exchange capacity etc. With these properties, organic matter has an indirect effect on soil fertility and plant growth. At the same time, in terms of nutrients that release with mineralization, organic matter has a direct effect on soil fertility and plant growth.

Humic acid (HA) and fulvic acid (FA) contain humic substances (HS), namely humus, which is an important component of the soil organic matter. Because of the different contribution ways on plant growth, HS are used in different areas of agriculture (Chen \& Aviad 1990). Owing to chelating properties of HS with metallic cations, availability of many nutrients increase and thus plant growth is affected positively (Stevenson 1994). Additionally, HS increase root and root hair growth leading to expanded root surface area and thus nutrient uptake capacity increases (Marschner 1995; Pinton et al 1999; Cesco et al 2002). A small part of lower molecular weight components in HS can be taken up by plants. With the hormone-like function, HS may increase cell membrane permeability. Addition of organic material may increase plant growth due to the effect of HS on nutrient in the soils (Chen \& Aviad 1990). Positive effects of HS on plant growth, yield and plant nutrient uptake can be supported by the previous findings of numerous researchers (Erdal et al 2000; Pilanalı \& Kaplan 2003; Çelik et al 2008; Morard et al 2011; Tahir et al 2011; Çimrin et al 2013; Cunha et al 2015). Although there are many studies showing the positive effect of HS on plant growth and plant nutrient uptake, negative or no effects of HS have been reported (Tahir et al 2011; Leventoglu \& Erdal 2014 ). Rauthan \& Schnitzer (1981) indicated that more than $300 \mathrm{mg}$ $\mathrm{kg}^{-1}$ of FA showed reducing effect on plant growth and nutrition uptake and these effects was below the control treatment at the levels of 1500 and 2000 $\mathrm{mg} \mathrm{kg}^{-1} \mathrm{FA}$. Similarly, reduction of plant growth has been observed at the higher dose of HS applications (Chen \& Aviad 1990). Nikbakht et al (2008) reported the non-significant effect of high levels of HS on fresh and dry weights of leaves. At the same study, nutrient concentrations increases with lower HA, but the higher levels of HA negatively affected some nutrient concentrations.

This study aimed to investigate the effects of HS applications on yield and mineral nutrition of Granny Smith and Jersey Mac apple varieties.

\section{Material and Methods}

The experiment was conducted as a field experiment for two consecutive years, 2012- 
2013 at Horticultural Research Institute, Egirdir, Isparta-Turkey. The experimental soil was clayey loam (Bouyoucos 1951) having $\mathrm{pH}$ of 7.74 (1:2.5 soil to water ratio), $3 \% \mathrm{CaCO}_{3}, 3.35 \%$ organic matter (Jackson 1962), $34 \mathrm{mg} \mathrm{kg}{ }^{-1} \mathrm{NaHCO}_{3}$ extractable P (Olsen et al 1954), 565, 4811, 1235 $\mathrm{mg} \mathrm{kg} 1 \mathrm{~N} \mathrm{NH}_{4} \mathrm{OAC}$ exchangeable $\mathrm{K}$ and $\mathrm{Ca}$ and $\mathrm{Mg}$ (Knudsen et al 1982). DTPA extractable $\mathrm{Fe}, \mathrm{Cu}, \mathrm{Zn}$ and $\mathrm{Mn}$ concentrations (Lindsay \& Norwell 1978) were 14, 13, 5 and $14 \mathrm{mg} \mathrm{kg}^{-1}$, respectively. As basal fertilization, $30 \mathrm{~kg} \mathrm{ha}^{-1} \mathrm{~N}$, $42.2 \mathrm{~kg} \mathrm{ha}^{-1} \mathrm{P}, 40 \mathrm{~kg} \mathrm{ha}^{-1} \mathrm{~K}$ were applied using ammonium nitrate, mono ammonium phosphate and potassium nitrate. Thirteen year-old Granny Smith (GS) and Jersey Mac (JM) apple varieties grafted on MM106 which are planted as $3.0 \times 3.5 \mathrm{~m}$ were used as plant materials. As humic substance, "TKİ HUMAS" containing 12\% HA+FA (pH: 12) was used. The experiment was planned according to randomized blocks with 5 replications and each replicate consisted of one tree. For soil application (S) 4 levels of humic substances (-HS, S1, S2 and S3) corresponding to $0,50,100$ and $200 \mathrm{~kg} \mathrm{ha}^{-1}$ were given to each tree root zone around the tree canopy. As foliar application (L), 2\% of HS was applied three times with one week intervals in June. Soil applications were made in early spring. Applications were repeated in the second years.

In order to determine leaf nutrient concentrations, samples were collected from the four sides of trees from the present year's shoots (Bergmann 1992). Then, samples were brought to laboratory and washed with water, dilute acid $(0.2 \mathrm{~N} \mathrm{HCl})$ and distilled water. Later, samples were dried at $65 \pm 5 \mathrm{C}^{\circ}$ for 2 days. Afterwards, samples were dried, grounded and wet digested with microwave oven. Total $\mathrm{N}$ was determined according to Kjeldahl method. Leaf P concentration was measured spectrophotometrically (Shimadzu UV-1208, $430 \mathrm{~nm}$ ), K, Ca, Mg, Fe, Cu, Zn, and Mn concentrations were determined using atomic absorption spectrophotometer (Kacar \& İnal 2008). Harvest of fruits was performed three times for JM in July and once for GS in October. Fruit weight, height and width were measured by digital scale and caliper with 20 randomly selected fruit from each tree. Fruit flesh firmness was detected from the two equatorial points of the fruit using hand penetrometer with $11.1 \mathrm{~mm}$ probe. Soluble solids content was measured using a digital refractometer. Pomological characteristics of the Jersey Mac apple fruits were conducted on the second harvest. Data was subjected to statistical analysis using Co Stat statistical software and the means were grouped using DUNCAN test.

\section{Results}

Although application of humic substance had no significant effect on fruit yield for both years, slight increases in fruit yield were recorded (Table 1). While the lowest yield was obtained from the control treatments for both varieties and two years, yields showed increment up to $19 \%$ and $8 \%$ for JM and GS cultivars, respectively. In general, fruit yields, fruit weights, heights and widths of JM and GS varieties were not affected from HS applications for both years, but in the second year fruit heights were negatively affected from soil+leaf applications (Table 2). According to the first year results, HS application did not affect fruit flesh firmness, soluble solids and $\mathrm{pH}$ for both varieties. However, fruit flesh firmness and soluble solids in JM variety were affected

Table 1- Effects of HS applications on yield

\begin{tabular}{lcccc}
\hline \multirow{2}{*}{ Applications } & \multicolumn{4}{c}{ Yield $\left(\mathrm{kg}^{\text {tree }} \mathrm{e}^{-1}\right)$} \\
\cline { 2 - 5 } & \multicolumn{2}{c}{ First year } & \multicolumn{2}{c}{ Second year } \\
\cline { 2 - 5 } & $J M$ & $G S$ & $J M$ & $G S$ \\
\hline -HS & 26.8 & 40.0 & 27.8 & 41.8 \\
S1 & 28.0 & 42.0 & 29.0 & 44.0 \\
S2 & 28.9 & 42.4 & 30.0 & 44.4 \\
S3 & 30.3 & 43.0 & 31.4 & 45.0 \\
L & 30.5 & 42.4 & 31.6 & 44.4 \\
S1+L & 31.6 & 43.2 & 32.8 & 45.2 \\
S2+L & 31.1 & 42.0 & 33.0 & 44.0 \\
S3+L & 31.2 & 41.6 & 32.4 & 43.6 \\
\hline
\end{tabular}

JM, Jersey Mac; GS, Granny Smith 
Table 2- Effects of HS applications on fruit weight, height and width

\begin{tabular}{lllllll}
\hline \multirow{2}{*}{ Applications } & \multicolumn{7}{c}{ Weight $(\mathrm{g})$} & \multicolumn{3}{c}{ Height $(\mathrm{mm})$} & \multicolumn{3}{c}{ Width $(\mathrm{mm})$} \\
\cline { 2 - 7 } & Jirst year & GS & $J M$ & $G S$ & $J M$ & $G S$ \\
\hline -HS & 111 & 220 & 65 & 81 & 54 & 73 \\
S1 & 122 & 210 & 68 & 80 & 56 & 70 \\
S2 & 127 & 196 & 69 & 78 & 57 & 68 \\
S3 & 132 & 219 & 69 & 80 & 58 & 71 \\
L & 124 & 225 & 69 & 82 & 52 & 70 \\
S1+L & 120 & 190 & 68 & 70 & 56 & 61 \\
S2+L & 111 & 191 & 65 & 73 & 53 & 67 \\
S3+L & 134 & 196 & 69 & 77 & 58 & 67 \\
& \multicolumn{7}{c}{ Second year } & & & \\
-HS & 130 & 211 & 67 & $79 \mathrm{a}$ & 56 & 70 \\
S1 & 115 & 194 & 64 & $77 \mathrm{a}$ & 57 & 79 \\
S2 & 126 & 205 & 68 & $79 \mathrm{a}$ & 58 & 69 \\
S3 & 130 & 205 & 69 & $78 \mathrm{a}$ & 59 & 71 \\
L & 119 & 217 & 68 & $81 \mathrm{a}$ & 59 & 82 \\
S1+L & 127 & 201 & 68 & $69 \mathrm{~d}$ & 61 & 73 \\
S2+L & 138 & 180 & 70 & $74 \mathrm{~b}$ & 62 & 67 \\
S3+L & 120 & 202 & 66 & $73 \mathrm{c}$ & 58 & 64 \\
\hline
\end{tabular}

JM, Jersey Mac; GS, Granny Smith; *, no significant differences between the same letters $(\mathrm{P}>0.05)$ in the same column; for each column, the numbers without letters indicate non-significance

significantly from the applications at the second year $(\mathrm{P}<0.05)$. While individual effect of soil and leaf applications had a positive effect on fruit flesh firmness, negative effect was observed by combine application of soil and leaf. Soil applications had a negative effect on soluble solids amount, but leaf and soil+leaf combinations were ineffective. In the second year, HS applications did not affect flesh firmness, soluble solids and $\mathrm{pH}$ of GS apples (Table 3).

Effects of HS application on leaf N, P, K, Ca and $\mathrm{Mg}$ concentrations are summarized in Table 4. As can be seen from the table, only leaf $\mathrm{N}$ and $\mathrm{K}$ concentrations of $\mathrm{JM}$ were affected from the applications at the first year. In this variety, leaf $\mathrm{N}$
Table 3- Effects of HS applications on fruit flesh firmness, soluble solids and $\mathrm{pH}$

\begin{tabular}{|c|c|c|c|c|c|c|}
\hline \multirow{2}{*}{ Applications } & \multicolumn{2}{|c|}{ Firmness (lb) } & \multicolumn{2}{|c|}{ Soluble solids (\%) } & \multicolumn{2}{|c|}{$p H$} \\
\hline & $J M$ & $G S$ & $J M$ & $G S$ & $J M$ & $G S$ \\
\hline \multicolumn{7}{|c|}{ First year } \\
\hline -HS & 7.7 & 8.7 & 9.8 & 9.3 & 3.1 & 2.1 \\
\hline S1 & 7.2 & 8.7 & 9.5 & 11.7 & 3.1 & 2.2 \\
\hline $\mathrm{S} 2$ & 7.2 & 9.1 & 9.1 & 11.4 & 3.0 & 2.2 \\
\hline S3 & 6.6 & 8.5 & 10.1 & 11.6 & 3.0 & 2.2 \\
\hline $\mathrm{L}$ & 7.3 & 8.6 & 9.6 & 11.5 & 3.0 & 2.6 \\
\hline $\mathrm{S} 1+\mathrm{L}$ & 7.6 & 9.4 & 9.8 & 12.9 & 3.0 & 2.3 \\
\hline $\mathrm{S} 2+\mathrm{L}$ & 7.3 & 9.4 & 9.2 & 12.7 & 3.0 & 2.3 \\
\hline $\mathrm{S} 3+\mathrm{L}$ & 7.2 & 8.3 & 9.9 & 11.5 & 3.0 & 2.3 \\
\hline \multicolumn{7}{|c|}{ Second year } \\
\hline -HS & $6.2 b^{*}$ & 7.4 & $10.8 \mathrm{a}$ & 14.0 & 3.2 & 2.1 \\
\hline S1 & $7.1 \mathrm{a}$ & 8.8 & $9.5 \mathrm{c}$ & 14.5 & 3.2 & 2.2 \\
\hline S2 & $6.8 \mathrm{a}$ & 7.4 & $9.1 \mathrm{c}$ & 13.5 & 3.3 & 2.2 \\
\hline S3 & $6.8 \mathrm{a}$ & 8.7 & $10.1 \mathrm{~b}$ & 14.0 & 3.3 & 2.2 \\
\hline $\mathrm{L}$ & $7.2 \mathrm{a}$ & 8.1 & $10.7 \mathrm{a}$ & 13.4 & 3.1 & 2.5 \\
\hline $\mathrm{S} 1+\mathrm{L}$ & $5.9 \mathrm{~b}$ & 7.9 & $10.7 \mathrm{a}$ & 13.4 & 3.1 & 2.3 \\
\hline $\mathrm{S} 2+\mathrm{L}$ & $5.3 \mathrm{c}$ & 7.9 & $11.0 \mathrm{a}$ & 13.8 & 3.2 & 2.3 \\
\hline $\mathrm{S} 3+\mathrm{L}$ & $6.0 \mathrm{~b}$ & 8.3 & $10.6 \mathrm{a}$ & 13.8 & 3.1 & 2.3 \\
\hline
\end{tabular}

JM, Jersey Mac; GS, Granny Smith; *; no significant differences between the same letters in the same column $(\mathrm{P}>0.05)$; for each column, the numbers without letters indicate non-significance

concentrations increased with the leaf and soil+leaf applications. In the second year, leaf $\mathrm{N}$ concentration of both varieties were affected positively from HS applications and leaf $\mathrm{N}$ concentrations of JM and GS varieties increased about $34 \%$ and $25 \%$ respectively $(\mathrm{P}<0.05)$.

For both varieties, soil+leaf combinations gave the best results in terms of leaf $\mathrm{N}$ concentrations generally. Leaf $\mathrm{K}$ concentration was affected positively from HS applications $(\mathrm{P}<0.05)$. For first year, it was observed that S2 and S3 applications and their combinations with leaf application had the higher effects than the other applications in JM variety. Furthermore, K concentration of GS 
Table 4- Effects of HS applications on N, P, K, Ca and Mg concentrations of leaves (\%)

\begin{tabular}{|c|c|c|c|c|c|c|c|c|c|c|}
\hline \multirow{2}{*}{ Applications } & \multicolumn{2}{|c|}{$N$} & \multicolumn{2}{|c|}{$P$} & \multicolumn{2}{|c|}{$K$} & \multicolumn{2}{|c|}{$\mathrm{Ca}$} & \multicolumn{2}{|c|}{$M g$} \\
\hline & $J M$ & $G S$ & $J M$ & $G S$ & $J M$ & $G S$ & $J M$ & $G S$ & $J M$ & $G S$ \\
\hline \multicolumn{11}{|c|}{ First year } \\
\hline -HS & $2.33 \mathrm{c}^{*}$ & 2.36 & 0.27 & 0.25 & $1.33 \mathrm{~b}$ & 1.35 & 1.28 & 0.73 & 0.35 & 0.27 \\
\hline S1 & $2.37 \mathrm{c}$ & 2.20 & 0.28 & 0.24 & $1.37 \mathrm{~b}$ & 1.33 & 1.26 & 0.85 & 0.35 & 0.25 \\
\hline S2 & $2.38 \mathrm{c}$ & 2.27 & 0.28 & 0.25 & $1.50 \mathrm{a}$ & 1.30 & 1.38 & 0.89 & 0.33 & 0.26 \\
\hline S3 & $2.44 \mathrm{~b}$ & 2.34 & 0.29 & 0.26 & $1.46 \mathrm{a}$ & 1.29 & 1.29 & 0.91 & 0.32 & 0.27 \\
\hline $\mathrm{L}$ & $2.64 \mathrm{a}$ & 2.25 & 0.28 & 0.25 & $1.33 \mathrm{~b}$ & 1.43 & 1.31 & 0.96 & 0.32 & 0.27 \\
\hline $\mathrm{S} 1+\mathrm{L}$ & $2.55 \mathrm{a}$ & 2.03 & 0.27 & 0.23 & $1.40 \mathrm{~b}$ & 1.21 & 1.09 & 0.74 & 0.32 & 0.24 \\
\hline $\mathrm{S} 2+\mathrm{L}$ & $2.56 \mathrm{a}$ & 2.13 & 0.29 & 0.25 & $1.49 \mathrm{a}$ & 1.25 & 1.28 & 0.78 & 0.31 & 0.27 \\
\hline $\mathrm{S} 3+\mathrm{L}$ & $2.52 \mathrm{a}$ & 2.29 & 0.29 & 0.24 & $1.51 \mathrm{a}$ & 1.30 & 1.29 & 0.81 & 0.29 & 0.26 \\
\hline \multicolumn{11}{|c|}{ Second year } \\
\hline -HS & $1.46 \mathrm{c}$ & $1.50 \mathrm{c}$ & 0.29 & 0.20 & 1.46 & $0.58 \mathrm{~b}$ & $1.63 \mathrm{a}$ & $1.09 \mathrm{c}$ & $0.42 \mathrm{a}$ & 0.26 \\
\hline $\mathrm{S} 1$ & $1.47 \mathrm{c}$ & $1.55 \mathrm{c}$ & 0.31 & 0.21 & 1.48 & $0.68 \mathrm{~b}$ & $1.35 \mathrm{c}$ & $1.10 \mathrm{c}$ & $0.30 \mathrm{~d}$ & 0.25 \\
\hline S2 & $1.84 \mathrm{a}$ & $1.72 \mathrm{~b}$ & 0.33 & 0.28 & 1.44 & $1.06 \mathrm{a}$ & $1.87 \mathrm{a}$ & $1.26 \mathrm{~b}$ & $0.36 \mathrm{~b}$ & 0.29 \\
\hline S3 & $1.76 \mathrm{~b}$ & $1.53 \mathrm{c}$ & 0.33 & 0.29 & 1.51 & $0.95 \mathrm{a}$ & $1.64 \mathrm{a}$ & $1.29 \mathrm{~b}$ & $0.35 \mathrm{~b}$ & 0.29 \\
\hline $\mathrm{L}$ & $1.72 \mathrm{~b}$ & $1.71 \mathrm{~b}$ & 0.32 & 0.26 & 1.48 & $0.96 \mathrm{a}$ & $1.70 \mathrm{a}$ & $1.29 \mathrm{~b}$ & $0.38 \mathrm{a}$ & 0.27 \\
\hline $\mathrm{S} 1+\mathrm{L}$ & $1.86 \mathrm{a}$ & $1.87 \mathrm{a}$ & 0.30 & 0.25 & 1.55 & $0.96 \mathrm{a}$ & $1.34 \mathrm{~d}$ & $1.30 \mathrm{~b}$ & $0.33 \mathrm{c}$ & 0.25 \\
\hline $\mathrm{S} 2+\mathrm{L}$ & $1.91 \mathrm{a}$ & $1.82 \mathrm{a}$ & 0.29 & 0.28 & 1.58 & $1.06 \mathrm{a}$ & $1.45 \mathrm{~b}$ & $1.33 \mathrm{~b}$ & $0.34 \mathrm{~b}$ & 0.27 \\
\hline $\mathrm{S} 3+\mathrm{L}$ & $1.96 \mathrm{a}$ & $1.83 \mathrm{a}$ & 0.29 & 0.25 & 1.57 & $1.15 \mathrm{a}$ & $1.56 \mathrm{~b}$ & $1.38 \mathrm{a}$ & $0.38 \mathrm{a}$ & 0.26 \\
\hline
\end{tabular}

JM, Jersey Mac; GS, Granny Smith; *; no significant differences between the same letters in the same column (P>0.05); for each column, the numbers without letters indicate non-significance

variety was not influenced from applications at the first year. Second year, effect of HS on K nutrition of GS was quite noticeable. As seen from the table, leaf $\mathrm{K}$ concentration of GS increased up to 2 fold with HS applications (except S1). Potassium concentration in JM variety was not affected from HS in this year. Additionally, in the second year, leaf $\mathrm{Ca}$ concentrations showed considerable increase with HS applications in GS variety. For leaf $\mathrm{Ca}$ and $\mathrm{Mg}$ concentrations of $\mathrm{JM}$, it can be said that whether the effects of HS were similar to control or the effects of them were negative mostly. Effects of HS applications on Fe concentration of both apple variety in the first and the second years were significant $(\mathrm{P}<0.05)$. As can be seen from the first year's results, leaf Fe concentrations were the lowest at control treatments (-HS). However, leaf $\mathrm{Fe}$ concentrations with $\mathrm{HS}$, especially soil+leaf applications, increased remarkably for $\mathrm{GS}$ and JM varieties. Effects of $\mathrm{HS}$ on $\mathrm{Cu}, \mathrm{Zn}$, $\mathrm{Mn}$ and $\mathrm{B}$ concentrations of two apple varieties were not significant in the first year. In the second year, leaf $\mathrm{Fe}$ concentrations increased with the some of the HS applications. In this year, leaf and soil+leaf applications had higher effects than that of others on leaf Fe concentration. Another important finding in the second year is that $\mathrm{Zn}$ concentration of GS showed noteworthy increment with soil+leaf combinations. Leaf $\mathrm{Cu}$, $\mathrm{Mn}$ and $\mathrm{B}$ concentrations were not influenced significantly in this year (Table 5). 
Table 5- Effects of HS applications on $\mathrm{Fe}, \mathrm{Cu}, \mathrm{Zn}, \mathrm{Mn}$ and $\mathrm{B}$ concentrations of leaves (mg kg-1)

\begin{tabular}{|c|c|c|c|c|c|c|c|c|c|c|}
\hline \multirow{2}{*}{ Applications } & \multicolumn{2}{|c|}{$\mathrm{Fe}$} & \multicolumn{2}{|c|}{$\mathrm{Cu}$} & \multicolumn{2}{|c|}{$Z n$} & \multicolumn{2}{|c|}{$M n$} & \multicolumn{2}{|c|}{$B$} \\
\hline & $J M$ & $G S$ & $J M$ & $G S$ & $J M$ & $G S$ & $J M$ & $G S$ & $J M$ & $G S$ \\
\hline \multicolumn{11}{|c|}{ First year } \\
\hline -HS & $73 \mathrm{c}^{*}$ & $76 \mathrm{~b}$ & 12 & 11 & 29 & 15 & 17 & 22 & 36 & 34 \\
\hline S1 & $75 c$ & $79 \mathrm{~b}$ & 10 & 10 & 28 & 14 & 15 & 25 & 36 & 31 \\
\hline $\mathrm{S} 2$ & $82 \mathrm{~b}$ & $78 \mathrm{~b}$ & 11 & 10 & 27 & 14 & 14 & 22 & 38 & 33 \\
\hline $\mathrm{S} 3$ & $83 \mathrm{~b}$ & $82 \mathrm{~b}$ & 11 & 10 & 26 & 13 & 15 & 23 & 37 & 32 \\
\hline $\mathrm{L}$ & $83 \mathrm{~b}$ & $81 \mathrm{~b}$ & 11 & 10 & 26 & 13 & 14 & 23 & 37 & 31 \\
\hline $\mathrm{S} 1+\mathrm{L}$ & $92 \mathrm{a}$ & 95 a & 11 & 10 & 26 & 14 & 14 & 35 & 39 & 29 \\
\hline $\mathrm{S} 2+\mathrm{L}$ & 93 a & 89 a & 11 & 10 & 25 & 13 & 14 & 25 & 40 & 33 \\
\hline $\mathrm{S} 3+\mathrm{L}$ & $95 \mathrm{a}$ & $91 \mathrm{a}$ & 11 & 11 & 26 & 14 & 15 & 26 & 39 & 31 \\
\hline \multicolumn{11}{|c|}{ Second year } \\
\hline -HS & $77 \mathrm{c}$ & $105 \mathrm{~b}$ & 9 & 8 & 25 & $20 \mathrm{~b}$ & 19 & 20 & 43 & 30 \\
\hline $\mathrm{S} 1$ & $76 \mathrm{c}$ & $100 \mathrm{~b}$ & 7 & 8 & 19 & $20 \mathrm{~b}$ & 21 & 20 & 35 & 30 \\
\hline S2 & $81 \mathrm{~b}$ & $130 \mathrm{a}$ & 8 & 7 & 24 & $20 \mathrm{~b}$ & 23 & 20 & 39 & 31 \\
\hline S3 & $75 \mathrm{c}$ & $109 \mathrm{~b}$ & 7 & 7 & 18 & $22 \mathrm{~b}$ & 18 & 22 & 38 & 30 \\
\hline $\mathrm{L}$ & $92 \mathrm{a}$ & $124 \mathrm{a}$ & 8 & 6 & 19 & $23 \mathrm{~b}$ & 23 & 23 & 39 & 30 \\
\hline $\mathrm{S} 1+\mathrm{L}$ & $91 \mathrm{a}$ & $134 \mathrm{a}$ & 8 & 7 & 20 & $27 \mathrm{a}$ & 18 & 27 & 40 & 28 \\
\hline $\mathrm{S} 2+\mathrm{L}$ & $86 \mathrm{~b}$ & $132 \mathrm{a}$ & 7 & 7 & 20 & $27 \mathrm{a}$ & 21 & 27 & 39 & 29 \\
\hline $\mathrm{S} 3+\mathrm{L}$ & $93 \mathrm{a}$ & $134 \mathrm{a}$ & 8 & 8 & 25 & $30 \mathrm{a}$ & 20 & 30 & 41 & 30 \\
\hline
\end{tabular}

JM, Jersey Mac; GS, Granny Smith; *; no significant differences between the same letters in the same column (P>0.05); for each column, the numbers without letters indicate non-significance

\section{Discussion}

Except for the second year's fruit height of GS, humic substance applications did not affect fruit yield and quality parameters statistically for both years $(\mathrm{P}>0.05)$. Although relative yield increases were recorded for both varieties for two years, these increases were not significant. The effect of HS applications on mineral nutrition of apple varieties varied with the years. While only N, K and Fe were affected positively from $\mathrm{HS}$ applications in the first year, $\mathrm{Ca}$ and $\mathrm{Zn}$ were added to these nutrients in the second year. From these results it can be said that HS applications were more efficient in the second year. These results may be related to increment of organic matter content and mineralization at the second year (Demir \& Çimrin 2011). In addition chelating properties of HS on some metals can play a role in increasing of Zn and Fe in leaf(Fallahi et al 2006). One reason for increasing of leaf $\mathrm{K}$ concentrations in leaves can be due to $\mathrm{K}$ concentrations that come from the $\mathrm{KOH}$ used for HS production. Increasing of $\mathrm{Ca}$ concentration in the leaves of GS variety can be explained with the promotion of $\mathrm{Ca}$ uptake with increasing of $\mathrm{K}$ uptakes by plants (Özkan \& Yaman 2009). Some nutrient concentrations in leaves did not change with the HS applications. Similar results were found with the study conducted by Leventoglu \& Erdal (2014) and they explained the ineffectiveness of HS under some soil conditions. Focusing on the nutrient concentrations of trees, it is clear that both varieties showed different respons to HS applications. As explained before, different plant varieties or even different genotypes of same variety can vary in terms of nutrient uptake even they grow in the same environment (Tsipouridis \& Thomidis 2005; Jimenez et al 2007; Küçükyumuk \& Erdal 2009; Küçükyumuk et al 2015). Although some nutrient concentrations of plants did not increase, residual nutrients in the soil decreased. One of these results can be related to 
dilution of nutrient in plant tissues due to increased vegetative growth with HS applications (Kolsarıc1 et al 2005). The other reason may be transforms of nutrient to the insoluble forms as organo-mineral complex due to soil HS applications (Strickland et al 1979; White \& Chaney 1980; De Nobili et al 2002). Moreover, in some studies it is indicated that HS can compete with the nutrients for root uptake (Chen \& Aviad 1990).

Humic materials are generally applied to the soil, and affect the some physical, chemical and microbiological properties of it. However as found in this study, foliar sprays of these substances under field conditions increased the concentrations of N, K, Fe and $\mathrm{Zn}$ in leaves (Fernandez-Escobar et al 1996). Additionally, Brownell et al (1987) and Katkat et al (2009) indicated that spraying of leonardite extracts promoted the growth of tomato, cotton, grape and wheat. This growth promoting functions of HS, may be due to plant hormone-like materials in the HS (O’Donnell 1973; Casenave de Sanfilippo et al 1990).

In conclusion, effect of HS showed different behaviors on nutrients availability thus nutrient concentrations in plants. Although HS applications did not have positive effect on leaf $\mathrm{P}, \mathrm{Mg}, \mathrm{Mg}, \mathrm{Cu}$, $\mathrm{Mn}$ and $\mathrm{B}$ concentrations, leaf $\mathrm{N}, \mathrm{K}, \mathrm{Ca}, \mathrm{Fe}$ and $\mathrm{Zn}$ concentrations were affected positively from the HS applications. The shape and degree of influence of HS on mineral nutrition of apples showed variation depending on the variety. Even though there was no statistically effect; proportional yield increases were obtained from both varieties with HS applications.

\section{Acknowledgements}

We thanks to SDU BAP for supporting this work as a master thesis project

\section{References}

Bergmann W (1992). Nutritional Disorders of Plants: Development, visual and analytical diagnosis. Gustav Fischer Verlag

Bouyoucos G J (1951). A recalibration of the hydrometer method for making mechanical analysis of the soils. Agronomy Journal 43: 434-438
Brownell J R, Nordstrom G, Marihart J \& Jorgensen G (1987). Crop responses from two new leonardite extracts. Science of the Total Environment 62: 491-499

Casenave de Sanfilippo E, Arguello J A, Abdala G \& Orioli G A (1990). Content of auxin, inhibitor and gibberellin-like substances in humic acids. Biologia Plantarum 32: 346-351

Cesco S, Nikolic M, Romheld V, Varanini Z \& Pinton $\mathrm{R}$ (2002). Uptake of ${ }^{59} \mathrm{Fe}$ from soluble ${ }^{59} \mathrm{Fe}$-humate complexes by cucumber and barley plants. Plant and Soil 241: 121-128

Chen Y \& Aviad T (1990). Effects of humic substances on plant growth. In: P MacCarthy, C E Clapp, R L Malcolm \& P R Bloom (Eds), Humic substances in soil and crop sciences: Selected readings, Soil Science Society of America, pp. 161-186

Cunha M D S, Cavalcante Í H L, Mancin A C, Albano F G \& Marques A S (2015). Impact of humic substances and nitrogen fertilizing on the fruit quality and yield of custard apple. Acta Scientiarum. Agronomy 37(2): 211-218

Çelik H, Katkat A V, Asık B B \& Turan M A (2008). Effects of soil applied humic substances to dry weight and mineral nutrients uptake of maize under calcareous soil conditions. Archives of Agronomy and Soil Science 54: 605-614

Çimrin K M, Türkmen Ö, Turan M \& Tuncer B (2013). Phosphorus and humic acid application alleviate salinity stress of pepper seedling. African Journal of Biotechnology 9(36): 5845-5851

De Nobili M, Catalano L, Siebner-Freibach H \& Chen Y (2002). Sorption of microbial and synthetic ligands and chelates on organic matter and clays: A Physicochemical and iron supply study. XI ISINIP Book of Abstracts. pp. 32

Demir E \& Çimrin K M (2011). Effects of sewage sludge and humic acid applications on yield, nutrients and heavy metal contents of maize and some soil properties. Journal of Agricultural Sciences 17: 204-216

Erdal İ, Yurdakul İ \& Aydemir O (2004). Fertility status of apple orchards in Isparta district. Third National Fertilizer Congress, Agriculture, Industry, Environment, 11-13 October, Tokat, Turkey, pp. 1061-1070

Erdal I, Bozkur M A, Cimrin K M, Karaca S \& Saglam M (2000). Effects of humic acid and phosphorus applications on growth and phosphorus uptake of corn plant (Zea mays L.) grown in a calcareous soil. Turkish Journal of Agriculture and Forestry 24: 663-668 
Fallahi E, Fallahi B \& Seyedbagherib M M (2006). Influence of humic substances and nitrogen on yield, fruit quality and leaf mineral elements on 'early spur Rome' apple. Journal of Plant Nutrition 29(10): 1819-1833

Fernandez-Escobar R, Benlloch M, Barranco D, Duenas A \& Gañán J G (1996). Response of olive trees to foliar application of humic substances extracted from leonardite. Scientia Horticulturae 66(3): 191-200

Jackson M L (1962). Soil Chemical Analysis. PrenticeHall, Inc., Englewood Cliffs, N.S

Jimenez S, Pinochet Y, Gogorcena J A, Betra'n J A \& Moreno M A (2007). Influence of different vigor cherry rootstocks on leaves and shoots mineral composition. Scientia Horticulturae 112: 73-79

Kacar B \& İnal A (2008). Bitki Analizleri. Nobel, 1241 Ankara, Türkiye, s. 115-140

Katkat A V, Çelik H, Turan M A \& Asik B B (2009). Effects of soil and foliar applications of humic substances on dry weight and mineral nutrients uptake of wheat under calcareous soil conditions. Australian Journal of Basic and Applied Sciences 3(2): 1266-1273

Knudsen D, Peterson G A \& Pratt P F (1982). Lithium, sodium and potassium. In: Methods of soil analysis, Part 2. Chemical and microbiological properties. Exchangeable Cations. pp. 159-165

Kolsarıcı Ö, Kaya M D, Day S, İpek A \& Uranbey S (2005). Effects of humic acid doses on emergence and seedling growth of sunflower (Helianthus annuus L.). Journal of the Faculty of Agriculture, Akdeniz University 18(2): 151-155

Küçükyumuk Z \& Erdal I (2009). Rootstock and variety effects on mineral nutrition of apple trees. Suleyman Demirel University, Journal of the Faculty of Agriculture 4(2): 8-16

Küçükyumuk Z, Küçükyumuk C, Erdal İ \& Eraslan F (2015). Effect of different sweet cherry rootstocks and drought stress on nutrient concentrations. Tartm Bilimleri Dergisi-Journal of Agricultural Sciences 21(3): 431-438

Leventoglu H \& Erdal İ (2014). Effect of high humic substance levels on growth and nutrient concentration of corn under calcareous conditions. Journal of Plant Nutrition 37(12): 2074-2084

Lindsay W L \& Norwell W A (1978). Development of A DTPA test for zinc, iron, manganese and copper. Soil Science Society of American Journal 42: 421-428

Marschner H (1995). Mineral Nutrition of Higher Plants. London: Academic Press
Morard P, Eyheraguibel B, Morard M \& Silvestre J (2011). Direct effects of humic-like substance on growth, water, and mineral nutrition of various species. Journal of Plant Nutrition 34: 46-59

Nikbakht A, Kafi M, Babalar M, Xia Y P, Luo A \& Etemadi N (2008). Effect of humic acid on plant growth, nutrient uptake, and postharvest life of gerbera. Journal of Plant Nutrition 31: 2155-2167

O'Donnell R W (1973). The auxin-like effects of humic preparations from leonardite. Soil Science 116: 106-112

Olsen S R, Cole A V, Watanabe F S \& Dean L A (1954). Estimation of available phosphorus in soil by extracting with sodium bicarbonate. U.S. Department of Agriculture Circulation, 939, Washington DC

Özkan Y \& Yaman F (2009). Effects of different organic material applications on the performance of granny smith apple cultivar and leaf nutrient content. Research Journal of Agricultural Sciences 2(2): 123-132

Pilanalı N \& Kaplan M (2003). Investigation of effects on nutrient uptake of humic acid applications of different forms to strawberry plants. Journal of Plant Nutrition 26: $835-843$

Pinton R, Cesco S, Santi S, Agnolon F \& Varanini Z (1999). Water-extractable humic substances enhance iron deficiency responses by Fe-deficient cucumber plants. Plant and Soil 210: 145-157

Rauthan B S \& Schnitzer M (1981). Effects of a soil fulvic acid on the growth and nutrient content of cucumber (Cucumis sativus) plants. Plant and Soil 63(3): 491-495

Stevenson F J (1994). Humus Chemistry: Genesis, Composition, Reactions. John Wiley \& Sons

Strickland R C, Chaney W R \& Lamoreaux R J (1979). Organic matter influences phytotoxicity of cadmium to soybeans. Plant and Soil 52(3): 393-402

Tahir M, Khurshid M, Khan M Z \& Kazmi M H (2011). Lignite-derived humic acid effect on growth of wheat plants in different soils. Pedosfer 21(1): 124-131

Tsipouridis C \& Thomidis T (2005). Effect of 14 peach rootstocks on the yield, fruit quality, mortality, girth expansion and resistance to frost damages of may crest peach variety and their susceptibility on phytophthora citrophtora. Scientia Horticulturae 103(4): 421-428

TÜİK (2014). Türkiye İstatistik Kurumu. http://www. tuik.gov.tr (Erişim tarihi: 06.05.2014)

White M C \& Chaney R L (1980). Zinc, cadmium and manganese uptake by soybean from two zinc-and cadmium-amended coastal plain soils. Soil Science Society of America Journal 44(2): 308-313 